\title{
Respiratory Health Problems and Use of Personal Protective Equipment among Poultry Farm Workers in Owerri Senatorial Zone, Nigeria
}

\author{
C. C. Iwuala ${ }^{1}$, J. N. Ihuoma*, H. I. Udujih ${ }^{2}$, O. G. Udujih ${ }^{1}$ and F. C. Ihuoma ${ }^{3}$ \\ ${ }^{1}$ Department of Public Health, School of Health Technology, Federal University of \\ Technology, Owerri, Nigeria \\ ${ }^{2}$ Department of Medical Laboratory Science, Faculty of Health Science, Imo State University, \\ Owerri, Nigeria \\ ${ }^{3}$ Department of Science Technology, School of Industrial and Applied Sciences, Federal \\ Polytechnic, Nekede, Owerri, Nigeria \\ *Corresponding author
}

\section{Keywords}

Respiratory health, Respiratory symptoms, Personal protective equipment, Poultry workers

Article Info

\section{Accepted:}

15 December 2019

Available Online:

20 January 2020

\section{A B S T R A C T}

The use of personal protective equipment is essential for preventing and controlling diseases experienced by poultry farm workers as respiratory ill health among poultry farm workers has been strongly associated with working in poultry farms. The current study was carried out to determine the respiratory health problems prevalent and the level of utilization of personal protective equipment among the poultry farm workers. The study was carried out between April and May 2018. A descriptive survey involving 400 poultry farm workers from 20 poultry farms recruited through a multistage sampling technique was carried out using semi-structured questionnaires for data collection. Chi square test was performed to determine the relationship between respiratory symptoms and duration of work years. From the study, Male workers were dominant and 50\% of the respondents had worked in the poultry industry for 1-4 years. Use of nose masks stood at $40 \%$; with respirators at an all low of $1 \%$. Phlegm production and breathlessness was reported in $65 \%$ and $30 \%$ of the respondents respectively and $0.5 \%$ of the respondents reported bronchial asthma as a preexisting health condition. The results have strong implication for the provision and enforcement of the use of appropriate PPE, establishment of occupational health services and improved poultry dust control in the poultry industry.

\section{Introduction}

Over the recent decades, the poultry industry has made tremendous adjustment and growth to meet the increasing demand for inexpensive and safe supply of meat and eggs (Gerber et al., 2007). This has been made possible by the continuous dedication of the personnel working in the industry (Mohammed et al., 2018). Despite these 
positive features, poultry farmworkers are constantly exposed to agents causing health hazards (Das et al., 2014) and experience the risks of respiratory health problems, allergies, bacterial, parasitic and viral infections (Adebowale and Adeyemo, 2016). According to Pagni et al., (2008), poultry farm workers carry out tasks such as feeding of birds, collection of eggs, laying down beddings/litter, cleaning and populating poultry houses, handling and inspection of birds, removal of litter/manure, fumigation of poultry houses amongst others. The most occupationally related health problems widely reported among poultry farm workers are respiratory health problem ranging from asthma, pneumonia, bronchitis and avian influenza(Ngajilo, 2014; Hamid et al., 2018; Guillam et al., 2013; Viegas et al., 2013; Vem et al., 2019)with symptoms such as cough, wheeze and phlegm production widely reported (Faria et al., 2006; le Bouquin et al., 2014; Jaiyesimi and Agbaje, 2015; Guillam et al., 2017; Hamid et al., 2018).These are mainly attributed to the inhalation of/and interaction with respiratory irritants by poultry workers in poultry farm settings as they spend considerably long period of time in the poultry farm, exposed to these hazards(Ngajilo, 2014; Jerez et al., 2014).

International Labor Organization(2011) revealed that the use of personal protective equipment as a preventive measure against workplace hazards among poultry workers is important; and suitable and sufficient personal protective equipment with regards to the type of work and risk involved should be used by workers and provided by employers. According to the European Commission (2012), personal protective equipment used in agricultural settings include gloves, boots, goggles, mouth/nose masks, breathing apparatus, hardhats and protective clothing. In developing countries, informal sectors are not yet properly covered by safety and health legislation as poultry workers rarely use personal protective equipment while exposed to high levels of respiratory irritants which contribute to respiratory health issues(Adebowale and Adeyemo, 2016; Borghetti et al., 2002, Nku et al., 2005). This study was conducted to determine the prevalent respiratory health problems and use of personal protective equipment among poultry workers in Owerri senatorial zone. It is envisaged that the results of this study will add to the body of knowledge on the respiratory health of poultry workers and provide data for health, agriculture and labor agencies for the advocacy on the use of personal protective equipment in the poultry industry.

\section{Materials and Methods}

\section{Study location}

The study was purposively conducted in Owerri senatorial zone of Imo State Nigeria. The zone selection was based on proximity, familiarity, cost and predominance of poultry farms. It is made up of nine local government areas; covering around $170 \mathrm{~km}^{2}$ and shares boundaries with Abia State by the east and Rivers State by the south. Its inhabitants engage primarily in agriculture, business and civil service (Unuegbu, 2012; Onyekwere et al., 2013). A typical poultry farm is a large shed of unsophisticated structure with a frame of shelter made of concrete and a roof of corrugated iron sheets. The flooring is generally concrete but some have earth floors. The poultry birds are confined and housed in litters of milled wood fiber (saw dust) or battery cages; with feeders and drinkers mounted. Mechanization is absent since labor is cheap and supply of electricity inconsistent. Climate control is zero, ventilation is strictly natural and lighting is artificial (except when electricity is available). The main activities of poultry workers in a poultry farm include 
feeding of birds, grooming of birds, collection of eggs, cleaning of poultry houses(breeding rooms); processes which generate dust; some of which is visible to the naked eye as seen on the walls, floors and ceiling (Pagni et al., 2008).

\section{Study population and design}

The study which was carried out between April and May 2018 utilized a cross sectional descriptive study design. The respondents comprised of poultry workers who have been in continuous employment at the farm for at least 6 months preceding the study. Sample size was calculated using the formulae for determining the sample size for infinite population since the exact number of poultry workers in Owerri senatorial zone was unknown; with sample size of 385 generated but rounded up to the nearest hundred. Thus sample size of 400 was taken. The sample formula is thus stated as;

$$
\mathrm{n}=\frac{z^{2} \diamond p(1-p)}{d^{2}}
$$

Where;

$\mathrm{Z}=1.96$ (at $95 \%$ confidence interval and $\pm 5 \%$ precision)

$\mathrm{p}=$ proportion /best guess of value of proportion of population that are poultry workers

$\mathrm{d}=$ tolerance (how close the proportion of interest is to the desired estimate)

Thus;

$$
\mathrm{n}=\frac{\frac{(1.96)^{2} * 0.5(1-0.5)}{0.05^{2}}}{0 .} 385 \text { poultry workers. }
$$

\section{Sampling method}

A multistage sampling technique was used to select respondents. In the first stage, five local government areas in the zone were selected randomly. In the second stage, purposive sampling was employed to select only registered commercial poultry farms in the selected local government areas. List of registered commercial poultry farms was obtained from the Imo State Agricultural Development Program. Thus, in each of the selected local governments, four commercial poultry farms were randomly selected to give a total of 20 farms. In the third stage, at each selected farms, random sampling was employed to select 20 respondents, giving a total of 400 participants.

\section{Data collection technique}

Data was collected using questionnaires distributed and collected by agricultural extension workers of the Imo State Agricultural Development Program who were familiar with the content of the questionnaire, manner of approach and location of the poultry farm selected. In cases where a respondent were unable to fill the questionnaire due to low literacy, the questions were translated and asked in local language and answers were recorded as given.

\section{Informed consent}

The approval of the research work was sorted and approved by the Department of Public Health, Federal University of Technology Owerri. An introduction letter was given to the managers/directors of the selected poultry farms before workers were interviewed. Informed consent was also obtained from each participant prior to the interview.

\section{Data analysis}

Data was analyzed using statistical package for social science (SPSS) version 20.0.

\section{Results and Discussion}

A total of 400 poultry workers were 
interviewed. Socio demographic characteristics of the poultry farm workers showed the mean age of respondents was 34.3 $(\mathrm{SD} \pm 6.785)$ years with the highest age range at 31-35 years. Majority of the respondents were males $(70 \%)$ and of the Igbo ethnic group $(87.5 \%)$. Educational attainment of the respondents ranged from secondary education $(55 \%)$ to non-formal education (2.5\%). $55 \%$ of the respondents spend 6 hours at their workplace; with $10 \%$ of the respondents working in the poultry industry for more than 15 years (Table 1).87.5\% of the respondents were aware of respiratory health problems associated with poultry farming (Figure 1); with $75 \%$ of the respondents indicating awareness of the use of Personal Protective Equipment while at work (Figure 2).

Table.1 Socio-demographic characteristics of the respondents

\begin{tabular}{|c|c|c|}
\hline \multirow{2}{*}{$\begin{array}{l}\text { Socio-demographic } \\
\text { characteristics }\end{array}$} & \multicolumn{2}{|c|}{ Study population $(\mathrm{N}=400)$} \\
\hline & Frequency & Percentage (\%) \\
\hline $\begin{array}{l}\text { Age : } \\
\text { 16- } 20 \text { years } \\
21-25 \text { years } \\
26-30 \text { years } \\
31-35 \text { years } \\
36-40 \text { years } \\
41-45 \text { years } \\
50 \text { years above }\end{array}$ & $\begin{array}{l}15 \\
40 \\
30 \\
140 \\
100 \\
70 \\
5\end{array}$ & $\begin{array}{l}3.75 \\
10 \\
7.5 \\
35 \\
25 \\
17.5 \\
1.25\end{array}$ \\
\hline $\begin{array}{l}\text { Sex: } \\
\text { Male } \\
\text { Female }\end{array}$ & $\begin{array}{l}280 \\
120\end{array}$ & $\begin{array}{l}70 \\
30\end{array}$ \\
\hline $\begin{array}{l}\text { Duration of work years: } \\
<1 \text { year } \\
1-4 \text { years } \\
5-9 \text { years } \\
10-14 \text { years } \\
>15 \text { years }\end{array}$ & $\begin{array}{l}20 \\
200 \\
100 \\
40 \\
40\end{array}$ & $\begin{array}{l}5 \\
50 \\
25 \\
10 \\
10\end{array}$ \\
\hline $\begin{array}{l}\text { Level of education: } \\
\text { No education } \\
\text { Primary education } \\
\text { Secondary education } \\
\text { Tertiary education }\end{array}$ & $\begin{array}{l}10 \\
30 \\
220 \\
140\end{array}$ & $\begin{array}{l}2.5 \\
7.5 \\
55 \\
35\end{array}$ \\
\hline $\begin{array}{l}\text { Number of hours spent at } \\
\text { workplace: } \\
1 \text { hour } \\
3 \text { hours } \\
6 \text { hours } \\
12 \text { hours }\end{array}$ & $\begin{array}{l}10 \\
140 \\
220 \\
30\end{array}$ & $\begin{array}{l}2.5 \\
35 \\
55 \\
7.5\end{array}$ \\
\hline $\begin{array}{l}\text { Ethnic group: } \\
\text { Igbo } \\
\text { Yoruba } \\
\text { Hausa }\end{array}$ & $\begin{array}{l}350 \\
40 \\
10\end{array}$ & $\begin{array}{l}87.5 \\
10 \\
2.5\end{array}$ \\
\hline
\end{tabular}


Table.2 Relationship between respiratory symptoms and duration of work years using Chi Square test

\begin{tabular}{|c|c|c|c|c|c|c|c|c|c|c|c|c|}
\hline \multirow{3}{*}{$\begin{array}{l}\text { Respiratory } \\
\text { symptoms }\end{array}$} & \multicolumn{10}{|c|}{ Work duration (years) } & \multirow{3}{*}{$\begin{array}{l}\square^{2} \\
\text { Test }\end{array}$} & \multirow{3}{*}{ p-value } \\
\hline & \multicolumn{2}{|c|}{$\begin{array}{l}\text { Less than } \\
1 \text { year }\end{array}$} & \multicolumn{2}{|c|}{$1-4$ years } & \multicolumn{2}{|c|}{ 5-9 years } & \multicolumn{2}{|c|}{$10-14$ years } & \multicolumn{2}{|c|}{$\begin{array}{l}15 \text { years and } \\
\text { above }\end{array}$} & & \\
\hline & Yes & No & Yes & No & Yes & No & Yes & No & Yes & No & & \\
\hline Cough & 18 & 2 & 200 & 0 & 92 & 8 & 0 & 40 & 40 & 0 & $\begin{array}{l}316.25 \\
1\end{array}$ & $.0000^{*}$ \\
\hline $\begin{array}{l}\text { Phlegm } \\
\text { production }\end{array}$ & 20 & 0 & 200 & 0 & 40 & 60 & 0 & 40 & 0 & 40 & $\begin{array}{l}294.50 \\
5\end{array}$ & $.0000^{*}$ \\
\hline breathlessness & 18 & 2 & 102 & 98 & 0 & 100 & 0 & 40 & 0 & 40 & $\begin{array}{l}153.42 \\
9\end{array}$ & $.0000^{*}$ \\
\hline wheeze & 18 & 2 & 112 & 88 & 0 & 100 & 0 & 40 & 0 & 40 & $\begin{array}{l}167.15 \\
7\end{array}$ & $.0000^{*}$ \\
\hline Chest tightness & 18 & 2 & 102 & 98 & 0 & 100 & 0 & 40 & 0 & 40 & $\begin{array}{l}153.42 \\
9\end{array}$ & $.0000^{*}$ \\
\hline Chest pain & 18 & 2 & 102 & 98 & 0 & 100 & 0 & 40 & 0 & 40 & $\begin{array}{l}153.42 \\
9\end{array}$ & $.0000^{*}$ \\
\hline
\end{tabular}

Figure.1 Awareness on respiratory problems associated with poultry farming

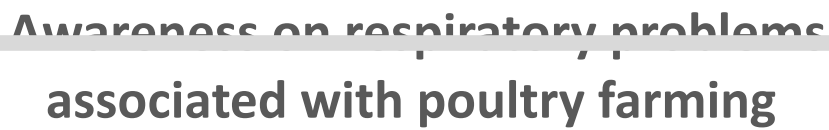


Figure.2 Awareness on use of PPE at workplace

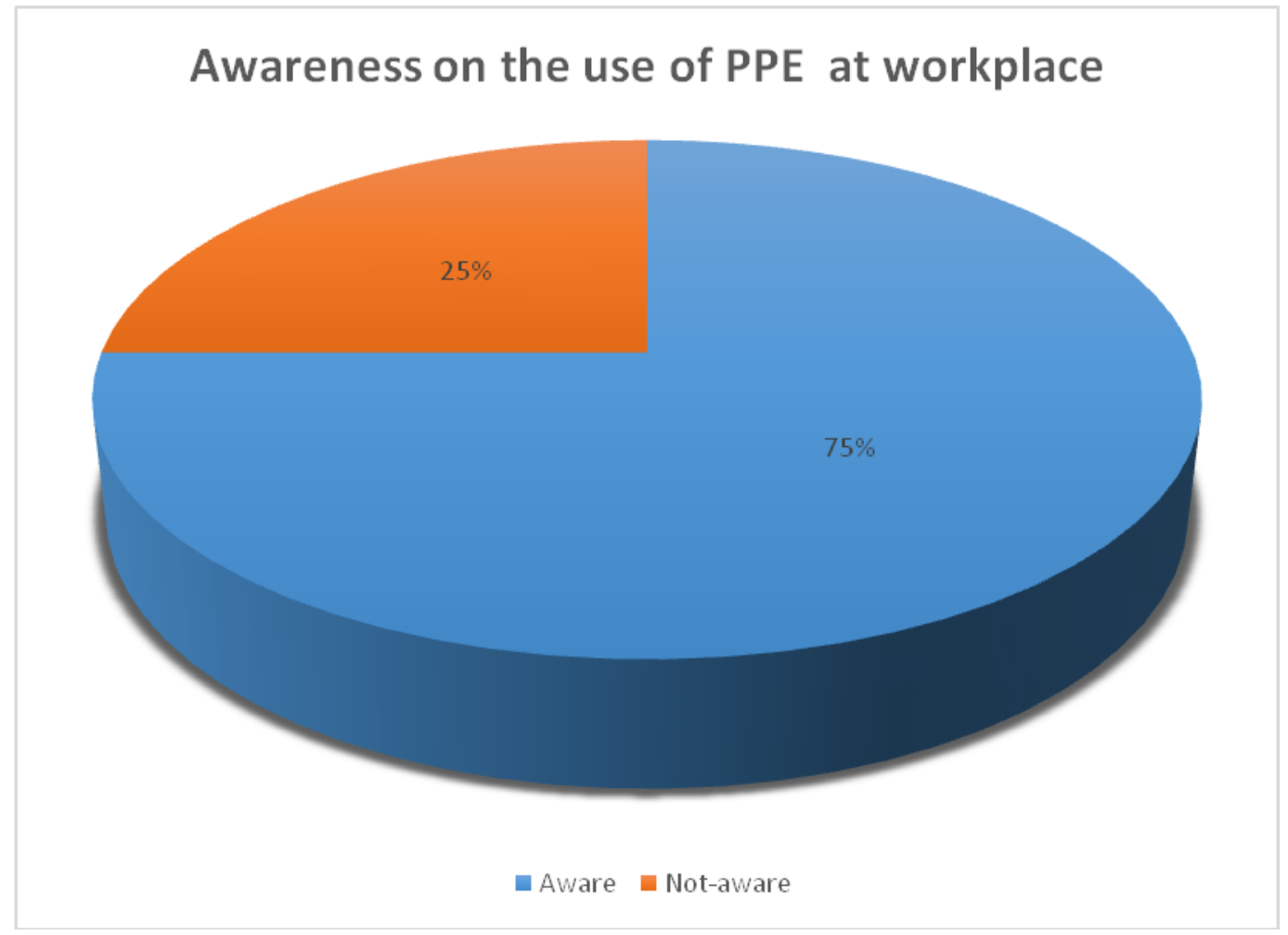

Figure.3 Level of utilization of PPE among poultry farm workers

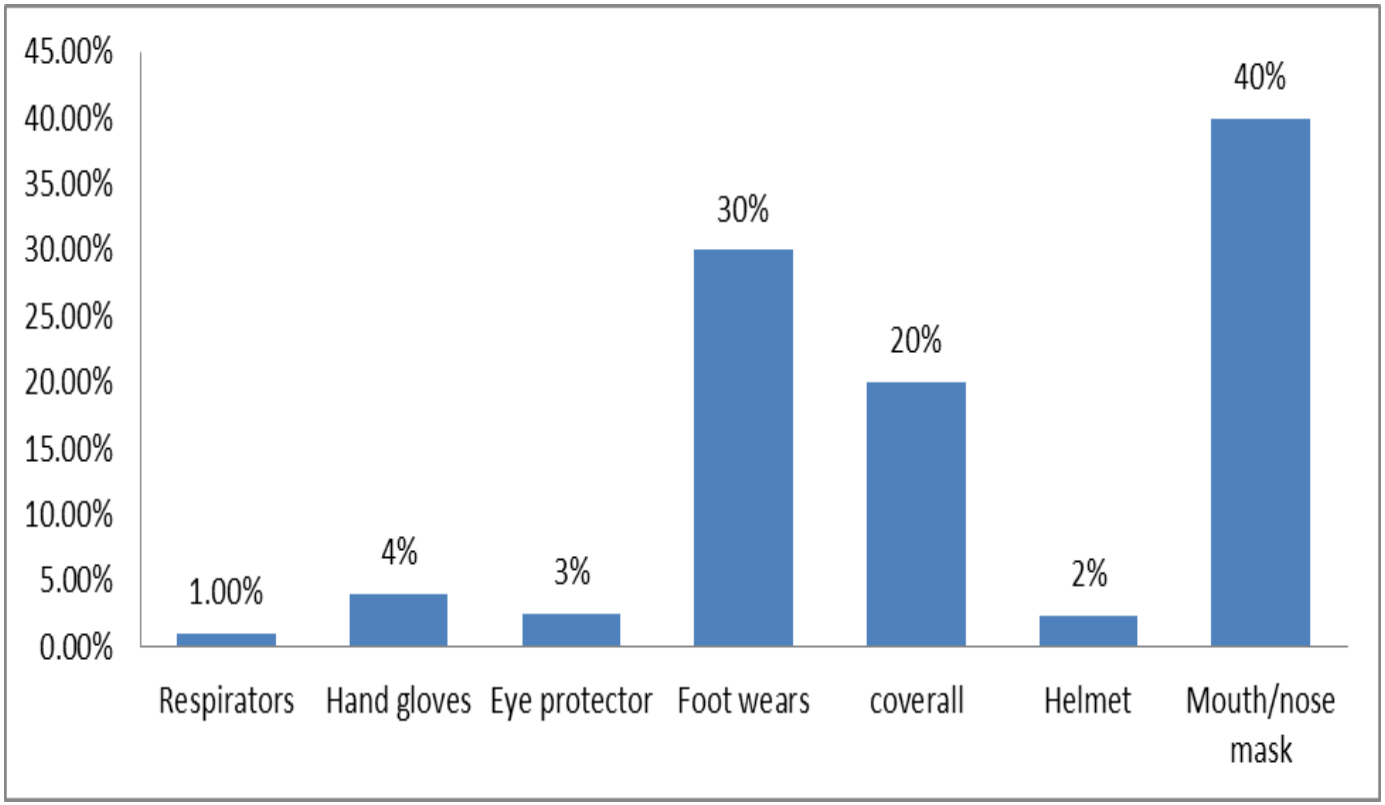


Figure.4 Prevalent respiratory symptoms among poultry farm workers

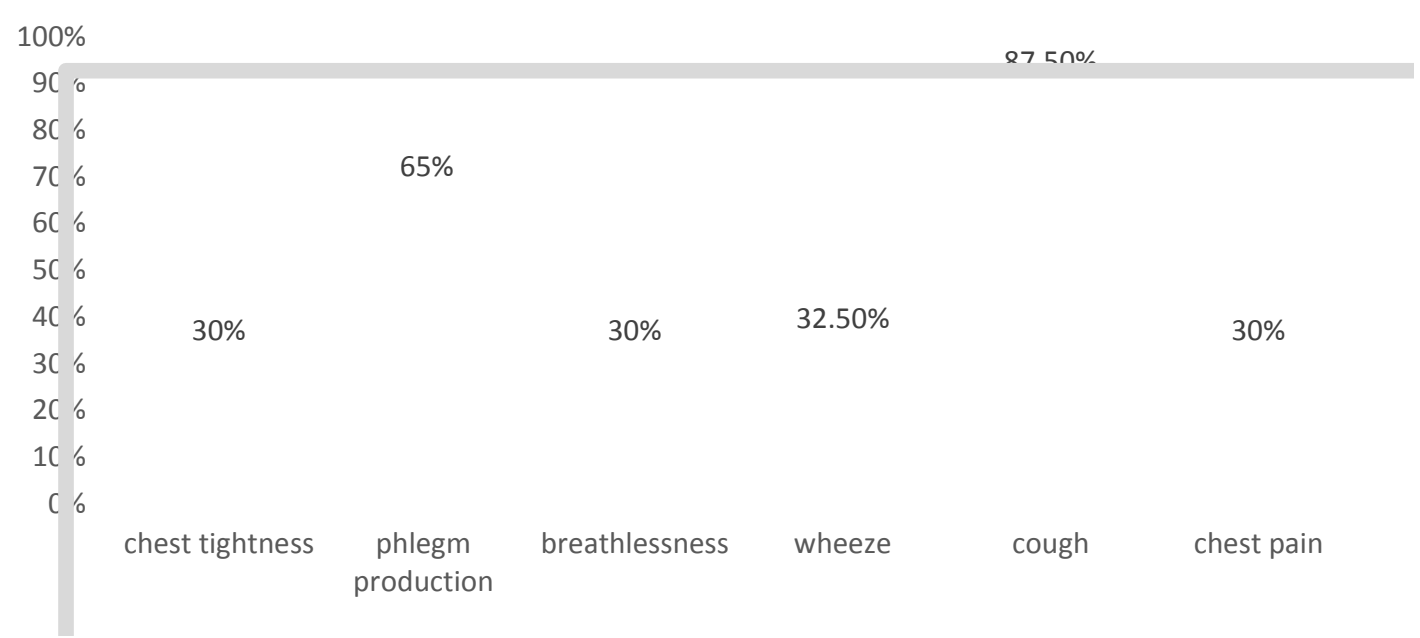

Figure.5 Preexisting respiratory health conditions among respondents as diagnosed by a medical personnel

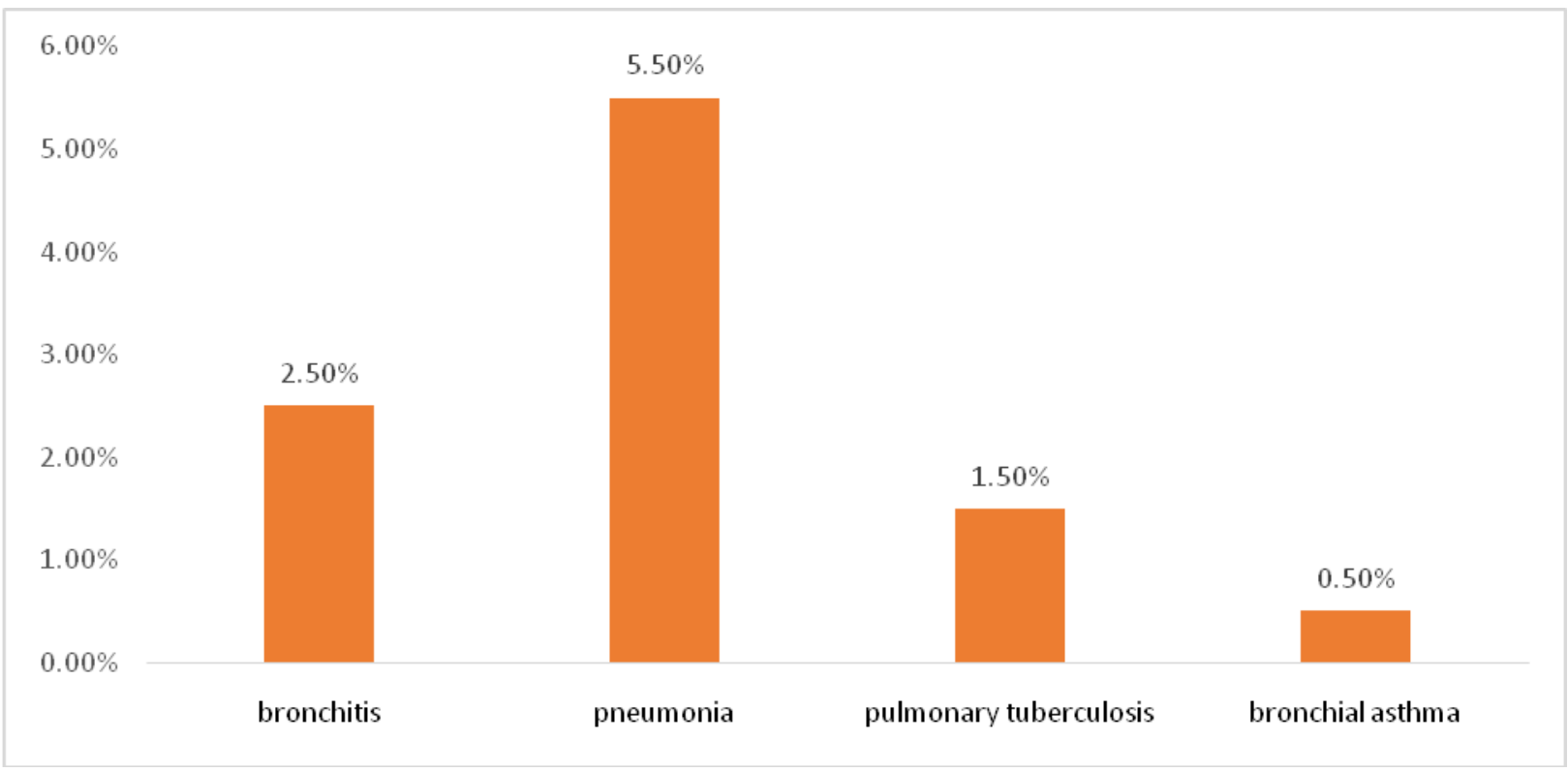

PPE used among the respondents was represented in Figure 3 with mouth/nose mask (40\%)being the most used PPE. Self-reported respiratory symptoms among the respondents represented in Figure 4 had cough, phlegm production, breathlessness and wheeze at $87.5 \%, 65 \%, 30 \%$ and $32.5 \%$ respectively. Preexisting respiratory health conditions among the workers were represented in Figure 5 with pneumonia (5.5\%) highly reported. Duration of work years had a significant influence on the presence of respiratory symptoms using the Chi Square test; as represented in Table 2.

In this study, male workers outnumbered the female workers and this finding is consistent with previous studies that attributed the hiring of male workers in poultry farmers (Faria et al., 2006; Viegas et al., 2013) as it is a 
physically demanding job (Ngajilo, 2014). The majority of the workers were 31-35 years old $(34 \pm 6.785)$ with $1.25 \%$ of the workers above 50 years. The healthy workers effect phenomenon may be a reason for this observation; as employers may reject certain persons due to physical disabilities or/and poor general health (healthy hire effect); or workers who do not have strong motivation to work because of health problems do not present themselves for employment and/or retire early (healthy worker survivor effect) (Shah, 2009; Chowdhury et al., 2017). Respondents were predominantly of the Igbo ethnic group and this is attributed to the fact that the study location is in a South Eastern state of Nigeria whose people are predominantly Igbo. Level of education ranged from secondary education $(55 \%)$ to no formal education $(2.5 \%)$ with majority of the respondents working in the industry for $1-4$ years.

According to Kearney et al., (2015), personal protective equipment has a definite role in the prevention and reduction of the myriad of health hazards (diseases) that poultry workers are exposed to at work. The poultry workers should use appropriate respiratory equipment for prevention of work related respiratory diseases; as work safety climate is associated with use of job appropriate PPE. In this study, $75 \%$ of the poultry workers reported they were aware of the use of PPE at work. A study comparing the use of PPE among Thai and Minnesota poultry farmers reported an all low use $1 \%$ use of PPE among Thai workers; and $26 \%$ use of nose mask and $51 \%$ use of gloves among Minnesota poultry farmers (Odo et al., 2015).A study on the use of PPE among poultry workers in England stood at protective coverall $81 \%$, protective footwear $82 \%$, disposable gloves $67 \%$, facemask $51 \%$, and protective goggles 19\% (Morgan et al., 2009). Studies on Nepal poultry workers reported the use of PPE at; facemask 27.1\%, gloves $30.2 \%$, and boots $7.3 \%$ and coverall $3.1 \%$ (Neupane et al., 2012). However in this study, the use of mouth/nose mask was $40 \%$, foot wears (boots) $30 \%$, coverall $20 \%$; with hand gloves and eye protector standing at $4 \%$ and $3 \%$ respectively. These observations could largely be due to prevalent norms and occupational safety and health regulations in these regions (Odo et al., 2015).

In this study, coughand phlegm production was reported at $87.5 \%$ and $65 \%$ respectively compared to chest pain and wheeze at 30\% and $32.5 \%$ respectively. Similar results have been reported in a study on poultry workers in Ibadan, Nigeria with cough at $49.3 \%$, phlegm at $56 \%$ and wheeze at $7.3 \%$ (Jaiyesimi and Agbaje, 2015). Studies on respiratory symptoms among poultry farmers in France reported cough at $79 \%$ and shortness of breath at $21 \%$ (Guillam et al., 2013). This finding as similarly reported by other investigators might be as a result of the fact that poultry dust irritates the cough receptors and causes mucositis in the upper respiratory tract leading to cough and phlegm production; mostly due to immune response against pathogenic biological agents (Viegas et al., 2013; Tobin et al., 2016). Cough usually indicates the presence of a disease usually a respiratory tract infection such as common cold, acute bronchitis, pneumonia or tuberculosis; and can be caused by smoking, choking and air pollution (Chung and Pavord, 2008). In this study wheeze, shortness of breath, chest pain and chest tightness occurred at almost similar frequencies. Ngajilo (2014), Javis (2016) and Kerkar (2018) revealed that these symptoms occurring together with cough has been associated with lower respiratory tract infections of pneumonia, bronchitis, bacterial meningitis, tuberculosis, bronchiolitis, scarlet fever and asthma.

Pneumonia was the highest case $(5.5 \%)$ of all preexisting health conditions as reported by 
the poultry workers. According to Smit et al., (2017) and Poulsen et al., (2018), ambient air pollution increases the risk of lower respiratory infections especially pneumonia; as exposure to air pollutants such as particulate matter induces oxidative stress in pulmonary macrophages and epithelial cells. This reduces the lungs defenses against bacterial pathogens and disrupts the composition of the oropharyngeal micro-biota thus increasing the susceptibility to respiratory infections. In this study, bronchitis and asthma were reported at $2.5 \%$ and $0.5 \%$ respectively. Studies by El-Saadawy et al., (2011) on poultry farm workers in Sharkia Governorate, Egypt reported bronchitis and asthma at $16.3 \%$ and $6.3 \%$ respectively. Studies by Hamid et al., (2018) on poultry farmworkers in Pakistan reported $1.4 \%$ asthma cases. The mechanism of occurrence of bronchitis and asthma has been attributed to dust in poultry farms containing inflammatory agents such as allergic fungi which have biologically potent components in the cell wall and cytoplasm (El-Saadawy et al., 2011).Cases of asthma are usually low among poultry farm workers and tends not to increase. Such low prevalence may be due to the fact that farmers with asthma are likely to quit their job due to exacerbation of their symptoms (Hamid et al., 2018).Viegas et al., (2013) and Mirabelli et al., (2012) pointed out that a respiratory specific healthy worker effect may be a reason for these observations; as individuals who are eligible to work in poultry farms but have allergies or respiratory health conditions do not seek employment in these farms or leave the job; leaving the healthier ones employed.

El-Saadawy et al., (2011) pointed out that duration of work years is a risk factor for acute and chronic respiratory symptoms; and respiratory symptoms have been reported among poultry farmworkers with 5 or more years of occupational exposure; with the odds of having cough, wheeze and breathlessness increasing as the years increase (Health and Safety Executive, 2009). In this study, duration of work years had significant influence on the prevalence of respiratory symptoms and respiratory symptoms were more pronounced among workers who have been in employed in the poultry farms for 1-4 years;

In conclusion, symptoms such as cough, phlegm production, breathlessness, and wheeze and chest pain were widely reported by the poultry farm workers. Use of protective personal equipment was low among the poultry farm workers. Duration of work years had a significant influence on the prevalence of respiratory symptoms. Pneumonia was the highest respiratory health condition reported by the poultry farm workers based on previous diagnosis by a medical personnel. Results obtained emphasizes the need for investment in the provision and enforcement of internationally recommended personal protective equipment such as respirators, appropriate and comfortable mouth and nose masks and protective goggle; and improved poultry dust control as this will help decrease the burden of respiratory diseases among poultry farmworkers. The establishment of welldeveloped occupational health services in the country is also highly recommended and health care providers should familiarize themselves with the agricultural activities that occur in their region so as to identify possible agents and be alert for relevant respiratory symptoms.

\section{References}

Adebowale O, Adeyemo O. (2016). Assessment of Workplace Health and Safety Measures among Poultry Workers in a Southwestern State of Nigeria. Italian Journal of Occupational 
and Environmental Hygiene, 7(2). www.ijoehy.it/index.php/IJOEHY/articl e/view/157. [Access date: 3.12.2017]

Borghetti C, Magarolae R, Badorrey I, Monso E. Sensitization and Occupational Asthma in Poultry Workers. Med Clin 2002; 118(7): 251-255.

Chowdhury R, Shah D, Payal AR. Healthy Worker Effect Phenomenon Revisited with Emphasis on Statistical Methods-A Review. Indian J Occup Environ Med 2017; 21(1): 2-8.

Chung, KF, Pavord ID. Prevalence, Pathogenesis and Causes of Chronic Cough. Lancet2008; 371(9621), 13641374.

Das SR, Begum N, Hoq MN, Hossain J. Awareness about Personal Protective Equipment and Health Problems among Poultry Workers. Northern International Medical College Journal 2014; 5(2): 336-338

El-Saadawy ME, Nassif MM, Abou El-Magd SA, Ahmed AS. Some occupational health problems among poultry farm workers in Sharkia Governorate: An epidemiological study. Journal of American Science 2011; 7(10): 561657.

European Commission (2012). Protecting health and safety of workers in agriculture, livestock farming, horticulture and forestry. https://osha.europa.eu/en/toolsandpublic ations/publications/ [Access date: 18.12.2018]

Faria NMX, Facchini LA, Fassa AG, Tomasi E. Farm work, dust exposure and respiratory symptoms among farmers. Rev Saude Publica 2006; 40 (5): 827836.

Gerber P, Opio C, Steinfeld H. (2007). Poultry production and the environment: a review. Animal production and health division, food and agriculture organization of the united nations, Vialedelleterme di Caracalla, 153.

https://scholar.google.com/poultryprodu ctionandtheenvironment [Access date: 24.08.2017]

Guillam MT, Martin S, Le Guelennec M, Puterflam J, Le Bouquin S, HuneauSalaun A. Dust Exposure and Health of Workers in Duck Hatcheries. Ann Agric Environ Med 2017; 24(3): 360-365.

Guillam M-T, Pedrono G, Le Bouquin S, Haueau A, Gaudon J, Leborgne R, et al., Chronic Respiratory Symptoms of Poultry Farmers and Model-Based Estimates of Long Term Dust Exposure. Ann Agric Environ Med 2013; 20 (2):307-311

Hamid A, Ahmad AS, Khan N. Respiratory and Other Health Risk among Poultry Farm Workerand Evaluation of Management Practices in Poultry Farms. Braz J Poultry Sci 2018;20(1): 111-118.

HSE Health and Safety Executive (HSE). (2009). Statement of Evidence: Respiratory Hazard of Poultry Dust. www.hse.gov.uk/pubns/web40.pdf.

[Access date: 24.08.2017]

International Labour Organization (2011). Safety and health in agriculture. www.ilo.org/safework/info/standardsan dinstruments/codes/WCMS. [Access date: 17.12.2018]

Jaiyesimi A, Agbaje S. Respiratory Symptoms and Lung Function Indices of Poultry Workers and Age Matched Apparently Healthy Individuals in Ibadan, Nigeria. Physiotherapy J 2015; 101(1): 667-668.

Javis S. (2016). Chest infections. Patient. www.patient.ifo/health/chestinfection. [Access date: 13.03.2018]

Jerez SB, Cheng Y, Bray J. Exposure of Workers to Dust and Bioaerosol on a Poultry Farm. J Appl Poult Res 2014; 23(1): 7-14. 
Kearney GD, Rodriguez G, Quandt SA, Arcury JT, Arcury TA. Work Safety Climate, Safety Behaviours and Occupational Injuries of Youth Farmworkers in North Carolina. American J Public Health 2015; 105(7):1336-1343.

Kerkar P. (2018) Bacterial Pneumonia: Causes, Signs, Symptoms, Investigations and Treatment. ePainAssist. www.epainassist,com/chestpain/lungs/c hestpaincausedbybacterialpneumonia [Access date: 13.03.2018]

Le Bouquin S, Yauschev-Raguenes S, Audren C, Wavelet E, Dewitte JD, Puterflam JC. (2014). Air Quality in Poultry Hacteries.

www.wpsa.com/index.php/publications/ wpsaproceedings/2014/xivth-europeanpoultry-conference. [Access date 17.12.2017]

Mirabelli MC, London SJ, Charles LE, Pompeii LS, Wagenknecht LE. Occupation and Three Year Incidence of Respiratory Symptoms and Lung Function Decline: The ARIC Study. Respir Res 2012; 13:24.

Mohammed HH, Rizk SM, Ebied EM. Occupational health hazards as perceived by poultry processing slaughterhouse workers. Med.J.Cairo Univ. 2018; 86(3): 1129-1138.

Morgan O, Kuhne M, Nair P, Verlander NQ, Preece R, McDougal M, et al., Personal Protective Equipment and Risk of Avian Influenza (H7N3). Emerg Infect Dis 2009; 15(1):59-62.

Neupane D, Khanal V, Ghimire K, Aro AR, Leppin A. Knowledge, Attitude and Practices Related to Avian Influenza among Poultry Workers in Nepal: A Cross Sectional Study. BMC Infect Dis 2012; 12: 76.

Ngajilo D. Respiratory Health Effects in Poultry workers. Curr Allergy Clin Im
2014;27(2):116-124.

Nku CD, Estiet AL, Oku O, Osim EE. Lung function, Oxygen saturation and symptoms among street sweepers in Calabar, Nigeria. Nig J Physiol 2005; 20(1-2):79-84.

Odo NU, Raynor PC, Beaudoin A, Somrongthong R, Scheftel JM, Donahue JG, et al., Personal protective equipment use and handwashing among animal farmers; a mutli site assessement. J Occup Environ Hyg 2015; 12(6):363-368.

Onyekwere OK, Ezebuiro VO, Samuel ES. Knowledge of Hypertension among Adults in Owerri Senatorial Zone of Imo State, Nigeria". Mediterr J Soc Sci 2013;4(4): 69-79.

Pagni P, Abimiku JEY, Okolie EM. (2008). Assessment of the Nigerian Poultry market chain to improve biosecurity. Food and Agriculture Organization of the United Nations, Nigeria. Retrieved from

www.fao.org/sustainablefoodvaluechain /library/details/en/c/270869 [Access date: on 2.08.2017]

Poulsen MN, Pollak J, Sills DL, Casey JA, Nachman KE, Cosgrove SE, et al., High Density Poultry Operations and Community Acquired Pneumonia in Pennsylvania. Environ Epidemiol 2018; 2(2): e13

Shah D. Healthy Worker Effect Phenomenon. Indian J Occup Environ Med 2009; 13(2):77-79.

Smit LAM, Boender GJ, de Steenhuijsen Piters WAA, Hagenaars TJ, Huijskens EGW, Rossen JWA, et al., Increased Risk of Pneumonia in Residents Living near Poultry Farms: Does the Upper Respiratory Tract Microbiota Play a Role? Pneumonia (Nathan) 2017; 9:3.

Tobin EA, Ediagbonya TF, Okojie OH, Asohun DA. Occupational exposure to wood dust and respiratory health status 
of sawmill workers in South-South Nigeria. J Pollution and Effluent Control 2016; 4(1), 154. DOI:10.4172/2375-4397.1000154

Unegbu VE. Information as a bane to ruralurban migration in local government areas in Nigeria. Arabian J Bus Manag Review (Kuwait Chapter) 2012; 2(3): 77-93.

Vem TS, Anejo-Okopi J, Dabak DJ, Ugwu BK, Bigwan EI, Kopkuk ED. et al.,
Avian influenza risk perception and preventive practice among poultry workers in Jos: a cross sectional study. American J Zool2019;2(1), 6-10.

Viegas S, Faisca VM, Dias H, Clerigo A, Carolino E, Viegas C. Occupational exposure to poultry dust and effects on the respiratory system in workers. $\mathrm{J}$ Toxicol Environ Health Part A 2013; 76(4-5): 20-239.

\section{How to cite this article:}

Iwuala, C. C., J. N. Ihuoma, H. I. Udujih, O. G. Udujih and Ihuoma, F. C. 2020. Respiratory Health Problems and Use of Personal Protective Equipment among Poultry Farm Workers in Owerri Senatorial Zone, Nigeria. Int.J.Curr.Microbiol.App.Sci. 9(01): 1796-1807. doi: https://doi.org/10.20546/ijcmas.2020.901.201 